\title{
1-MCP regulates ethylene biosynthesis and fruit softening during ripening of `Tegan Blue’ plum
}

\author{
Ahmad S. Khan and Zora Singh \\ Horticulture, Muresk Institute, Division of Resources and Environment \\ Curtin University of Technology, PO BOX 1987, Perth 6845, Western Australia, \\ Australia
}

\section{Corresponding author:}

Zora Singh

Associate Professor Horticulture

Curtin University of Technology, PO BOX 1987, Perth 6845, Western Australia, Australia

Phone: +61 892663138

Fax: $\quad+61892663063$

Email: Z.Singh@curtin.edu.au 


\section{Abstract}

To investigate the effects of postharvest application of 1-MCP on ethylene production, activities of ethylene biosynthesis enzymes including 1-aminocyclopropane carboxylic acid synthase (ACS), 1-amino-cyclopropane carboxylic acid oxidase (ACO) and 1-amino-cyclopropane carboxylic acid (ACC) content; and fruit softening enzymes such as pectin esterase (PE), exo-polygalacturonase (exo-PG), endo-polygalacturonase (endo-PG), as well as endo-1,4- $\beta$-D-glucanase (EGase) during plum fruit ripening, plum (Prunus salicina L. cv. Tegan Blue) fruit were exposed to $1-\mathrm{MCP}\left(0,0.5,1.0\right.$ or $\left.2.0 \mu \mathrm{L} \mathrm{L}^{-1}\right)$ at $20^{\circ} \pm 1^{\circ} \mathrm{C}$ for $24 \mathrm{~h}$. Following the treatments, fruit were allowed to ripen at ambient temperature $\left(20^{\circ} \pm 1^{\circ} \mathrm{C}\right)$, ethylene production in fruit, activities of ACS, ACO, ACC content and fruit softening enzymes (PE, EGase, exo-PG and endo-PG) in fruit skin and pulp were recorded at different intervals during fruit ripening period. Postharvest application of 1-MCP significantly delayed and suppressed the climacteric ethylene production and reduced the fruit softening during ripening period. 1MCP application significantly reduced the activities of ethylene biosynthesis enzymes ACS, ACO and ACC content in skin as well as in pulp tissues and the reduction was more pronounced with increased concentrations of 1-MCP applied. PE, EGase, exo-PG and endo-PG activities in the skin and the pulp were also significantly reduced with the application of $1-\mathrm{MCP}$. The reduction in activities of various fruit softening enzymes (PE, EGase, exo-PG and endo-PG) in skin as well as pulp tissues during ripening may attribute to direct inhibitory effect of 1-MCP on these fruit softening enzymes and /or due to the reduced biosynthesis of ethylene. 1-MCP treated fruit showed differential activities of fruit softening and ethylene biosynthesis enzymes in the skin and pulp tissues 
which warrant further investigation on regulation of gene expression related to these enzymes with 1-MCP treatment. In conclusion, 'Tegan Blue’ plum fruit treated with $1.0 \mu \mathrm{L} \mathrm{L}^{-1} 1-\mathrm{MCP}$ for 24 hours at $20^{\circ} \mathrm{C}$ suppressed and delayed ethylene production and reduced the activities of ethylene biosynthesis enzymes (ACS, ACO) and ACC content as well as various fruit softening enzymes (PE, EGase, exo-PG and endo-PG) in fruit skin and pulp tissues which may attribute directly to the reduced ethylene biosynthesis and/or inhibitory effect of 1-MCP on these fruit softening enzymes.

Keywords: ACC, ACO, ACS, EGase, ethylene, enzyme, 1-MCP, Prunus salicina L., PE, exo-PG, endo-PG, softening.

\section{Introduction}

The fruit ripening process in plum is regulated by endogenous ethylene biosynthesis (Abdi et al., 1997a; Lelievre et al., 1997a). Fruit softening is one of the indices of fruit maturity and ripening, which is partially controlled by endogenous ethylene biosynthesis (Abdi et al., 1997a; Menniti et al., 2004). The exogenous application of ethylene has also been reported to hasten the fruit softening in plum (Abdi et al., 1997a). The ethylene action inhibitor 1methylcyclopropane (1-MCP), which blocks the ethylene receptors (Sisler et al., 1996), has been reported to delay fruit softening and improve postharvest quality of climacteric fruits (Sisler and Serek, 1997), including different cultivars of plum (Abdi et al., 1998; Dong et al., 2001a; Skog et al., 2001; Dong et al., 2002; Martinez-Romero et al., 2003b; Salvador et al., 2003a; Skog et al., 2003; Valero 
et al., 2003; Khan and Singh, 2004; Menniti et al., 2004), peach and nectarine (Fan et al., 2002; Liguori et al., 2004), apricot (Fan et al., 2000; Dong et al., 2002) and cherry (Gong et al., 2002). 1-MCP application has also been reported to retard ethylene production and fruit softening in plum depending upon the cultivar (Abdi et al., 1998; Martinez-Romero et al., 2003a), maturity stage at harvest (Valero et al., 2003), concentration applied (Martinez-Romero et al., 2003a; Salvador et al., 2003a; Salvador et al., 2003b; Valero et al., 2003), duration of fruit exposure to 1-MCP (Abdi et al., 1998; Dong et al., 2001a; Dong et al., 2002), and fruit temperature at the time of 1-MCP application (Dong et al., 2001a; Blankenship and Dole, 2003).

The mode of action of 1-MCP is via the preferential attachment to the ethylene receptor at very lower concentration, thereby blocking the effect of both endogenous and exogenous ethylene, which reduces the physiological action of ethylene (Sisler and Serek, 1997). 1-MCP has been reported to be non-toxic for humans and the environment (Environmental Protection Agency, 2002).

Ethylene biosynthesis during fruit ripening proceeds from methionine, through S-adenosylmethionine (SAM) and 1-amino-cyclopropane carboxylic acid (ACC) to ethylene and is regulated by two key enzymes 1-aminocyclopropane carboxylic acid synthase (ACS) and 1-amino-cyclopropane carboxylic acid oxidase (ACO) (Mathooko et al., 2001; Alexander and Grierson, 2002). Inhibitory effects of 1-MCP on ethylene biosynthesis with reduced activity of ACS and ACO enzymes and their respective gene transcriptions has been reported in banana (Pathak et al., 2003) tomatoes (Nakatsuka et al., 1997) and peach (Mathooko et al., 2001). A higher activity of ACS was observed in 
control and 1-MCP treated 'Red Rosa' plum fruit as compared to ethylene treated fruit during ripening (Dong et al., 2001a).

Fruit softening is associated with cell wall disassembly (Seymour and Gross, 1996), and during fruit softening, pectin and hemicellulose in cell walls undergo solubilization and depolymerisation which contribute to cell wall loosening (Fischer and Bennett, 1991). Most of the studies on ripening related cell wall hydrolyses have examined the activities of pectin esterase, pectin lyase, polygalacturonase (PG) and Endo-1,4- $\beta$-D-glucanase (EGase) or cellulase enzymes in various fruits (Marin-Rodriguez et al., 2002; Jeong and Huber, 2004; Lohani et al., 2004). A dramatic increase in the activity of these enzymes, protein and mRNA levels have been observed during ripening in several climacteric fruits including tomato (Lashbrook et al., 1994), pear (Hiwasa et al., 2003) and avocado (Jeong et al., 2002). PG is an enzyme involved in the hydrolytic cleavage of $\alpha-(1-4)$ galacturonan linkage (Fischer and Bennett, 1991) and is the key activity responsible for pectin disassembly during fruit ripening (Sitrit and Bennett, 1998). 1-MCP application has been reported to affect the activity trend of cell wall enzymes in avocado fruit and to completely suppress the activity of PG enzymes during ripening (Jeong et al., 2002) . A difference in the cell wall enzymes activities in fruit pulp during the ripening of 1-MCP treated 'Red Rosa' plum was observed without any correlation with differences in fruit softening (Dong et al., 2001a).

As a prelude, 1-MCP is known to modulate the physiology of fruit softening process in different cultivars of plum during ripening. However, the effects of 1-MCP on the ethylene biosynthesis and cell wall hydrolysis enzymes during fruit ripening in skin has not been investigated and warrants further 
investigation. Therefore, the aim of the present study was to investigate how 1MCP application retards ethylene biosynthesis and fruit softening, including the activities of ethylene biosynthetic enzymes such as ACS, ACO and ACC content, as well as fruit softening enzymes including PE, exo-PG, endo-PG and EGase in the skin and pulp of the fruit during plum fruit ripening.

\section{Materials and Methods}

\section{$2.1 \quad$ Plant material}

Plum (Prunus salicina Lindel cv. Tegan Blue) fruit were harvested from Casuarina Valley Orchard at Manjimup (lat. $34^{\circ} 15^{\prime}$ S; long. $116^{\circ} 09^{\prime} \mathrm{E}$ ), in the South West region of Western Australia. Experimental trees were grafted on myrobalan (Prunus ceasefire Ehrh.) root stock, planted in 1987 in a North South direction, maintaining row distance of $4.5 \times 4.5 \mathrm{~m}$ and plant distance of $2 \times 2 \mathrm{~m}$, trained on a palmette training system and receiving similar commercial cultural practices. Plum fruit at commercial maturity (TSS $16.3 \pm 0.9 \%$ and firmness $60.3 \pm 2.6 \mathrm{~N}$ ) of uniform size, free from visual symptoms of any disease or blemishes were chosen for the experiment. The fruit were transported to the laboratory immediately after harvesting.

\subsection{1-MCP application}

The fruit were kept in a hermetically sealed plastic drum $(68 \mathrm{~L})$ and 0.0 , $0.5,1.0$ or $2.0 \mu \mathrm{L} \mathrm{L}^{-1} 1-\mathrm{MCP}$ concentrations were injected into the drums through 
a rubber septum. Required concentrations of 1-MCP were obtained from EthylBlock $^{\mathrm{TM}}$ powder (active ingredient $0.43 \%$ 1-MCP, BioTechnologies for Horticulture, Inc., IL, USA) following method of (Lalel et al., 2003). Fruit were treated with 1-MCP for 24 hours at $20^{\circ} \pm 1^{\circ} \mathrm{C}$ and allowed to ripen at room temperature $\left(20^{\circ} \pm 1^{\circ} \mathrm{C}\right)$. All treatments were replicated three times with eight fruit as an experimental unit. Experimental design was two-factorial, including 1MCP treatments and ripening time. Ethylene production was recorded daily during fruit ripening up to day 10 and during post ripening period to insure if there is any delayed climacteric ethylene production in 1-MCP-treated fruit. Whilst, the activities of ethylene biosynthesis enzymes, including 1-aminocyclopropane carboxylic acid synthase (ACS) EC 4.4.1.14, 1-aminocyclopropane carboxylic acid oxidase (ACO) EC 4.4.17.4 and of 1-aminocyclopropane carboxylic acid (ACC) content as well as fruit softening enzymes such as pectin esterase (PE) or pectin methyl esterase (PME) EC 3.1.1.11, Endo1,4- $\beta$-D-glucanase (EGase) or (cellulase) EC 3.2.1.4, Exo-Polygalacturonase (exo-PG) EC 3.2.1.67 and Endo-Polygalacturonase (endo-PG) EC 3.2.1.15 were estimated in fruit skin and pulp only on day 1, 4, 7 and 10 of fruit ripening.

\subsection{Estimation of ethylene production}

Two fruit per experimental unit were sealed in an airtight jar $(1000 \mathrm{ml})$ fitted with a rubber septum for one hour at room temperature $\left(21^{\circ} \pm 1^{\circ} \mathrm{C}\right)$. One ml of headspace gas sample was injected into Gas Chromatograph (GC) (Agilent Technologies, 6890 N Netwrok GC system, Palo Alto, California, U.S.A) fitted with a 2 m-long stainless steel supelco column (Porapack-Q 1/8”, mesh size 
80/100) and a flame ionization detector (FID). Nitrogen was used as carrier gas with a flow rate $20.0 \mathrm{~mL} \mathrm{~min}{ }^{-1}$. The temperature of the column, injector and detector was maintained at $110^{\circ} \mathrm{C}, 150^{\circ} \mathrm{C}$ and $250^{\circ} \mathrm{C}$ respectively. Ethylene in the gas was identified by comparing its retention time with authentic standards (1.1 $\mu \mathrm{L} \mathrm{L}^{-1}$ and $8.2 \mu \mathrm{L} \mathrm{L}^{-1}$ of ethylene in nitrogen) certified as $\beta$ standard and obtained from BOC Gases Australia Ltd. Ethylene production was expressed as $\mu \mathrm{mol} \mathrm{kg}{ }^{-1} \mathrm{~h}^{-1}$. To check the possibility of ethylene emissions from the rubber septum, a blank injection from the headspace of an empty jar was also run under similar conditions of analysis.

\section{$2.4 \quad$ Fruit firmness}

Fruit firmness was determined using an electronic pressure tester (model EPT-1 pressure tester, Lake City Technical Products Inc, Kelwona, BC, Canada) fitted with an 8-mm tip. A small slice of fruit skin was removed and firmness was recorded from two sides of individual plum fruit and then means were expressed as Newtons (N).

\subsection{Determination of activity of ethylene biosynthesis enzymes and ACC content in fruit skin and pulp}

Ethylene biosynthesis enzymes ACS and ACO and ACC content from fruit skin and pulp tissues were estimated by following the method of (Dong et al., 2001a), with some modifications. 


\subsubsection{Determination of ACS activity}

Skin or pulp tissue (10g) was homogenised with $5 \mathrm{~mL} \mathrm{K-phosphate}$ buffer $(0.5 \mathrm{M}, \mathrm{pH} 8.5)$ containing $5 \mu \mathrm{M}$ pyridoxal phosphate and $5 \mathrm{mM}$ dithiotheritol in the presence of $5 \%$ polyvinylpyrolidone (PVP) in a glass pestle and mortar using $400 \mathrm{mg}$ white quartz sand (-50+70 mesh, Sigma Alderich, Australia) at $2^{\circ} \pm 1^{\circ} \mathrm{C}$. Contents were centrifuged at $14000 \mathrm{~g}$ for $30 \mathrm{~min}$ at $4^{\circ} \mathrm{C}$ and $2 \mathrm{~mL}$ of supernatant was mixed with one $\mathrm{mL}$ of $500 \mu \mathrm{M}$ s-adenosyl methionine (SAM) into a glass reaction tube. The reaction tube was sealed with a rubber septum, incubated for $30 \mathrm{~min}$ at $30^{\circ} \mathrm{C}$, and transferred to an ice bath. Using a syringe through the stopper, $0.1 \mathrm{~mL}$ of $\mathrm{HgCl}_{2}(50 \mathrm{mM})$ and $0.3 \mathrm{~mL}$ of $\mathrm{NaOCl}(5 \%)$ and saturated $\mathrm{NaOH}(2: 1, \mathrm{v} / \mathrm{v})$ were added into the reaction tube. The reaction tube was incubated in ice for further $2.5 \mathrm{~min}$ and a $1 \mathrm{~mL}$ gas sample was taken form the head space and injected into the GC for ethylene estimation, as described earlier. Ethylene production was calculated from the peak area obtained from the tissue extract $(2 \mathrm{~mL})$ in comparison with the peak area obtained for the ethylene standard. ACS activity was expressed as pmol ACC mg $\operatorname{protein}^{-1} \mathrm{~h}^{-1}$

\subsubsection{Determination of ACO activity}

Skin or pulp tissue $(2 \mathrm{~g})$ was homogenised in a glass pestle and mortar using $200 \mathrm{mg}$ white quartz sand in $5 \mathrm{~mL}$ extraction buffer consisting of $0.1 \mathrm{M}$ Tris- $\mathrm{HCl}(\mathrm{pH} 7.2), 10 \%(\mathrm{w} / \mathrm{v})$ glycerol and $30 \mathrm{mM}$ sodium ascorbate in the presence of $5 \%$ PVP and the mixture was centrifuged at 14,000 g for $30 \mathrm{~min}$. All 
the steps in the enzyme extraction were carried out at $2^{\circ} \pm 1^{\circ} \mathrm{C}$. The enzyme was assayed in $2 \mathrm{~mL}$ reaction mixture containing $1.8 \mathrm{~mL}$ of the above supernatant solution, $0.1 \mathrm{~mL}$ ACC $(40 \mathrm{mM})$ and $0.1 \mathrm{~mL} \mathrm{FeSO}_{4}(1 \mathrm{mM})$. The reaction tube was sealed with a rubber septum and incubated at $30^{\circ} \mathrm{C}$ for $60 \mathrm{~min}$. One $\mathrm{mL}$ of gas was taken from headspace and injected into GC for ethylene estimation, as described earlier. Ethylene production was calculated from the peak area obtained from the tissue extract $(1.8 \mathrm{~mL})$, in comparison with the peak area obtained for the ethylene standard. ACC oxidase activity was expressed as nmol $\mathrm{C}_{2} \mathrm{H}_{4}$ mg $\operatorname{protein}^{-1} \mathrm{~h}^{-1}$.

\subsubsection{Determination of ACC content}

The fruit skin or pulp tissue (5-6 g) was homogenised in a glass pestle and mortar using $300 \mathrm{mg}$ white quartz sand with $10 \mathrm{~mL}$ distilled water at $2^{\circ} \pm$ $1^{\circ} \mathrm{C}$ temperature. Following centrifugation at $10,000 \mathrm{~g}$ for $20 \mathrm{~min}$ at $4^{\circ} \mathrm{C}, 0.5 \mathrm{~mL}$ supernatant was mixed with $0.1 \mathrm{~mL} \mathrm{HgCl}_{2}(50 \mathrm{mM})$ in two sets one with and the other without $0.1 \mathrm{~mL} \mathrm{ACC}(100 \mu \mathrm{M})$ and the final volume $1.8 \mathrm{~mL}$ was made with distilled water. The glass test tubes were sealed with a rubber septum. Both test tubes were placed on ice, and $0.2 \mathrm{~mL}(5 \% \mathrm{NaOCl}+$ saturated $\mathrm{NaOH} 2: 1$, v/v) solution was injected into the sealed tubes and vortexed for $5 \mathrm{sec}$. After 24 min incubation on ice, the tubes were again vortexed and $1 \mathrm{~mL}$ gas sample was taken from headspace and injected into GC for estimation of ethylene. The conditions of analysis were similar to those explained above. Ethylene production was calculated from the peak area obtained from the tissue extract 
$(0.5 \mathrm{~mL})$ in comparison with peak obtained for the sample without internal ACC $(0.1 \mathrm{~mL})$ as standard and was expressed as pmol $\mathrm{g}^{-1} \mathrm{FW}$.

\subsection{Determination of softening enzyme activity in fruit skin and pulp}

Softening enzymes, including exo-PG, endo-PG, EGase and PE from fruit skin and pulp tissues, were estimated by following the method of (Dong et al., 2001a), with some modifications.

\subsubsection{Determination of exo-PG and endo-PG activities}

The fruit skin or pulp tissue $(13 \mathrm{~g})$ was mixed with $13 \mathrm{ml}$ cold $12 \%$ polyethylene glycol and $0.2 \%$ sodium bisulphite. Contents were homogenised in a glass pestle and mortar using $400 \mathrm{mg}$ white quartz sand and centrifuged at $14000 \mathrm{~g}$ for $45 \mathrm{~min}$ at $4^{\circ} \mathrm{C}$. The pellet was washed with $13 \mathrm{ml}$ cold aqueous solution of sodium bisulphite $(0.2 \%)$ and re-centrifuged at $14000 \mathrm{~g}$ for $15 \mathrm{~min}$ at $4^{\circ} \mathrm{C}$, and was stored at $-80^{\circ} \mathrm{C}$ before further analysis. Pellet was incubated at $4^{\circ} \mathrm{C}$ for 1 hour in $15 \mathrm{~mL}$ cold $50 \mathrm{mM}$ sodium acetate buffer (pH 5) containing $0.5 \mathrm{M}$ $\mathrm{NaCl}$. Following the centrifugation at $14000 \mathrm{~g}$ for $15 \mathrm{~min}$ at $4^{\circ} \mathrm{C}$, supernatant was diluted 1:1 with $50 \mathrm{mM}$ sodium acetate buffer $(\mathrm{pH} 5)$ and was used as crude enzyme extract. The activity of exo-PG was determined using the method given by Gross (1982), with some modification. The enzyme extract $(0.15 \mathrm{~mL})$ was mixed with $0.15 \mathrm{~mL}$ polygalacturonic acid $(0.5 \%)$ in $50 \mathrm{mM}$ sodium acetate buffer ( $\mathrm{pH} 4.4)$ and the contents were incubated at $30^{\circ} \mathrm{C}$ for 18 hours. To determine the amount of galacturonic acid released, $2 \mathrm{~mL}$ borate buffer $(0.1 \mathrm{M})$ 
pH 9.0 and $0.3 \mathrm{~mL}$ cyanoacetamide $(1.0 \%)$ were added to the reaction mixture and boiled for $10 \mathrm{~min}$. The absorbance of the cooled solution was recorded at $274 \mathrm{~nm}$ and was calculated by making standard curve with galacturonic acid; it was expressed as $\mu \mathrm{g}$ galacturonic acid $\mathrm{mg} \operatorname{protein}^{-1} \mathrm{~h}^{-1}$. A Cannon-Fenske viscosity meter (Size-50, 2139 High Tech Road, State College, Pennsylvania, USA) was used to measure endo-PG activity. Three mL enzyme extract (as used for exo-PG) was mixed with $4.5 \mathrm{~mL}$ polygalacturonic acid $(2.0 \%)$ in $50 \mathrm{mM}$ sodium acetate buffer ( $\mathrm{pH} 4.4)$ and viscosity was measured immediately after adding enzyme extract and after 18 hours incubation at $30^{\circ} \mathrm{C}$. The viscosity meter was cleaned with acetone after each run and calibrated with distilled water. The activity of endo-PG enzyme was expressed as viscosity changes mg protein ${ }^{-1} \mathrm{~h}^{-1}$.

\subsubsection{Determination of PE activity}

To estimate the activity of PE, fruit skin or pulp tissue (13g) was passed through series of steps until pellet formation, as described in exo-PG and endoPG estimation. The pellet was resuspended in $15 \mathrm{~mL}(7.5 \%, \mathrm{NaCl}, \mathrm{w} / \mathrm{v})$ and $0.75 \%(\mathrm{w} / \mathrm{v})$ ethylenediamine tetra-acetic acid (EDTA) at $\mathrm{pH} 6.5$, and incubated for $10 \mathrm{~min}$ at $4^{\circ} \mathrm{C}$. Following centrifugation at $14000 \mathrm{~g}$ at $4^{\circ} \mathrm{C}$ for $15 \mathrm{~min}, 5 \mathrm{~mL}$ of supernatant (crude enzyme extract) was mixed with $20 \mathrm{~mL}(1.0 \%)$ citrus pectin and titrated against $0.01 \mathrm{~N} \mathrm{NaOH}$, while incubating at $30^{\circ} \mathrm{C}$ to maintain

pH 7.4 for $10 \mathrm{~min}$. The activity of PE was expressed as $\mathrm{mM} \mathrm{NaOH}$ mg protein $^{-1}$ $\mathrm{h}^{-1}$. 


\subsubsection{Determination of EGase activity}

Fruit skin or pulp tissue (13g) was used to estimate EGase activity. Pellet formed though similar procedure, as mentioned above for exo-PG and endo-PG estimation was stirred in $15 \mathrm{~mL}(0.1 \mathrm{M})$ citrate phosphate buffer, $\mathrm{pH} 6.0$ and 1.0 $\mathrm{M} \mathrm{NaCl}$ for 1 hour at $4^{\circ} \mathrm{C}$. Following centrifugation at $14000 \mathrm{~g}$ for $15 \mathrm{~min}$ at $4^{\circ} \mathrm{C}$, $3 \mathrm{~mL}$ supernatant (crude enzyme extract) was mixed with $6 \mathrm{~mL}(0.2, \mathrm{w} / \mathrm{v})$ carboxymethyl cellulose in citrate phosphate buffer. The viscosity was measured immediately after enzyme addition and 18 hours after incubation at $30^{\circ} \mathrm{C}$. The activity of EGase was expressed as viscosity changes mg protein ${ }^{-1} \mathrm{~h}^{-1}$.

\subsection{Protein determination}

Protein contents from fruit skin or pulp tissue were estimated using the method (Bradford, 1976), with some modification. $100 \mathrm{mg}$ coomassie brilliant blue (G-250) was dissolved in $50 \mathrm{ml}(95 \%)$ ethanol and $100 \mathrm{~mL}(85 \%)$ phosphoric acid (w/v) and content was diluted to one $\mathrm{L}$ with distilled water. The supernatant $(0.1 \mathrm{~mL})$ was taken into $12 \times 100 \mathrm{~mm}$ reaction tubes. Protein reagent $(5 \mathrm{~mL})$ was added into the reaction tube, and contents were vortexed for $5 \mathrm{sec}$. The absorbance at $595 \mathrm{~nm}$ was measured after $1 \mathrm{~min}$ and before 1 hour in $3 \mathrm{~mL}$ plastic disposable cuvettes against a reagent blank prepared from $0.1 \mathrm{~mL}$ of the appropriate buffer and $5 \mathrm{~mL}$ protein reagent. Standard curve was made, using known albumin bovine serum concentrations, and protein was expressed as $\mathrm{mg} \mathrm{g}$ ${ }^{1} \mathrm{FW}$. 


\section{$2.8 \quad$ Statistical analysis}

Data were subjected to analysis of variance (ANOVA), using Genstate 6 release (Lawes Agricultural Trust, Rothamsted Experimental Station, Rothamsted, U.K.). The effects of various treatments were assessed within ANOVA and least significance differences (Fisher's LSD) were calculated $(P \leq$ 0.05). All the assumptions of analysis were checked to ensure validity of statical analysis. Pearson correlations were performed between the ethylene production and ethylene biosynthesis enzymes, ethylene production and fruit softening enzyme activities; fruit firmness and ethylene biosynthesis, fruit firmness and fruit softening enzyme activity were performed using SPSS software package v.14.0 for Windows, USA.

\section{Results}

\subsection{Ethylene production}

1-MCP-treated fruit exhibited delayed and suppressed ethylene production, as compared to untreated fruit. On day one of ripening, untreated fruit showed 11.8-fold higher ethylene production than 1-MCP-treated fruit. In the control fruit, climacteric ethylene production peaked $\left(1.89 \mu \mathrm{mol} \mathrm{kg}^{-1} \mathrm{~h}^{-1}\right)$ on day six of ripening and declined gradually to $0.414 \mu \mathrm{mol} \mathrm{kg}^{-1} \mathrm{~h}^{-1}$ on day 16 (Fig. 1). While none of 1-MCP-treated fruit showed any increase in ethylene production until day eight of ripening, $0.5 \mu \mathrm{L} \mathrm{L}^{-1} 1$-MCP-treated fruit showed 
climacteric ethylene peak $\left(2.08 \mu \mathrm{mol} \mathrm{kg} \mathrm{k}^{-1}\right)$ nine days later than control fruit. Higher 1-MCP concentrations (1.0 and $\left.2.0 \mu \mathrm{L} \mathrm{L}^{-1}\right)$ delayed and suppressed climacteric peak in ethylene production and exhibited two-fold less ethylene $\left(0.925\right.$ and $\left.0.859 \mu \mathrm{mol} \mathrm{kg}^{-1} \mathrm{~h}^{-1}\right)$ than control fruit even on day 16 .

\subsection{Ethylene biosynthesis enzymes and ACC content in fruit skin and pulp}

\subsubsection{Activity of ACS}

1-MCP treatments suppressed ACS activity in skin and pulp tissues of treated fruit as compared to untreated fruit during ten days of ripening. In control fruit the activity of ACS increased as ripening progressed. On day ten of ripening, the skin tissue showed 13-fold higher activity (3.424 pmol ACC mg protein $^{-1} \mathrm{~h}^{-1}$ ) of ACS than day one of ripening. ACS activity in the skin of the all 1-MCP-treated fruit remained unchanged until day seven, and then $0.5 \mu \mathrm{L} \mathrm{L}^{-1} 1$ MCP-treated fruit showed a slight increase in their skin ACS activity about 3fold less than the control. Fruit treated with higher concentrations of 1-MCP (1.0 and $2.0 \mu \mathrm{L} \mathrm{L}^{-1}$ ) did not show any change in ACS activity in skin tissue even after ten days of ripening (Fig. 3A). Plum pulp tissue from fruit treated with $0.5 \mu \mathrm{L} \mathrm{L}^{-1}$ 1-MCP estimated $0.181 \mathrm{pmol}$ ACC $\mathrm{mg}_{\text {protein }}{ }^{-1} \mathrm{~h}^{-1} \mathrm{ACS}$ activity, while higher concentrations remained unchanged even at day ten. Peak ACS activity in pulp of control fruit was estimated on day ten $\left(0.25 \mathrm{pmol}\right.$ ACC mg protein $\left.{ }^{-1} \mathrm{~h}^{-1}\right)$, which was found to be 14-fold less than skin (Fig. 3A and 3B). Similarly, the pulp of 1-MCP-treated fruit exhibited less ACS activity as compared to skin. Trends in the reduction of ACS activities were similar both in skin and pulp 
tissues, but skin tissue exhibited higher ACS activity compared to pulp tissues (Fig. 3B).

\subsubsection{Activity of ACO}

ACO activity in skin and pulp tissues of the fruit treated with 1-MCP were reduced more than in control fruit (Fig. 4A and 4B), depending upon the 1MCP concentrations applied. Untreated fruit skin and pulp tissues exhibited normal climacteric peak of ACO activity on day seven, while among the 1-MCP treated fruit at lower concentration $\left(0.5 \mu \mathrm{L} \mathrm{L}^{-1}\right)$ showed a little rise in ACO activity on day seven, and higher concentrations of 1-MCP (1.0 and $\left.2.0 \mu \mathrm{L} \mathrm{L}^{-1}\right)$ did not show any climacteric rise in ACO activity. Trends in the skin and pulp ACO activity were similar, but skin tissue exhibited higher activity than the pulp tissue. Pulp tissue of untreated fruit exhibited seven-fold less ACO activity (3.18 nmol $\left.\mathrm{C}_{2} \mathrm{H}_{4} \mathrm{mg}_{\text {protein }}{ }^{-1} \mathrm{~h}^{-1}\right)$ than skin ACO activity $\left(23.52 \mathrm{nmol} \mathrm{C}_{2} \mathrm{H}_{4} \mathrm{mg}\right.$ protein $^{-1} \mathrm{~h}^{-1}$ ) on day seven, and later on it decreased. Although in 1.0 and $2.0 \mu \mathrm{L}$ $\mathrm{L}^{-1} 1$-MCP-treated fruit, ACO activity was higher in skin compared to pulp, without any climacteric peak, as exhibited by control and $0.5 \mu \mathrm{L} \mathrm{L}^{-1} 1-\mathrm{MCP}-$ treated skin and pulp tissues.

\subsubsection{ACC content}

ACC content significantly increased during ripening in control fruit, while a rise in ACC content was completely suppressed in the 1-MCP-treated fruit tissue, irrespective of concentration of 1-MCP applied. There was a sharp 
rise in ACC content in skin and pulp tissues of untreated control fruit during ripening (Fig. 5A and 5B). Skin exhibited six-fold (17.23 $\left.\mathrm{pmol} \mathrm{g}^{-1} \mathrm{FW}\right)$ and pulp 19-fold (6.81 $\left.\mathrm{pmol} \mathrm{g}^{-1} \mathrm{FW}\right)$ rise in ACC content at day ten compared to day one. Skin tissue ACC content of untreated fruit remained three-fold higher than pulp tissue. None of the 1-MCP-treated fruit (pulp or skin) tissue exhibited any rise in the ACC content during the ripening period.

\subsection{Fruit firmness}

Postharvest 1-MCP application significantly delayed fruit softening during ripening at $20^{\circ} \pm 1^{\circ} \mathrm{C}$. Untreated control fruit exhibited a sharp decline in fruit firmness $(60.4 \mathrm{~N})$ at day one to $(25.6 \mathrm{~N})$ day four as compared to 1-MCPtreated fruit and finally the control fruit softened to $15.2 \mathrm{~N}$ on day ten (Fig. 2). During the first seven days of ripening, the firmness in all the 1-MCP-treated fruit remained the same; later on $0.5 \mu \mathrm{L} \mathrm{L}^{-1} 1$-MCP-treated fruit became softer $(23.9 \mathrm{~N})$ compared to $1.0 \mu \mathrm{L} \mathrm{L}^{-1}(35.6 \mathrm{~N})$ and $2.0 \mu \mathrm{L} \mathrm{L}^{-1}(37.4 \mathrm{~N})$ 1-MCP-treated fruit. The loss of fruit firmness in 1.0 and $2.0 \mu \mathrm{L} \mathrm{L}^{-1} 1$-MCP-treated fruit delayed significantly compared to other treatments but were at par with each other.

\subsection{Fruit softening enzymes in fruit skin and pulp}

\subsubsection{Activity of PE}

The application of 1-MCP reduced the activities of softening enzymes compared to the untreated control fruit. The effect of 1-MCP on the reduction of enzyme activity was concentration dependent and was more pronounced at 
higher concentrations of 1-MCP applied. Untreated fruit showed a linear increase in skin PE activity from day one $\left(0.064 \mathrm{mM} \mathrm{NaOH} \mathrm{mg} \mathrm{protein}{ }^{-1} \mathrm{~h}^{-1}\right)$ to day ten $\left(0.29 \mathrm{mM} \mathrm{NaOH} \mathrm{mg} \mathrm{protein}{ }^{-1} \mathrm{~h}^{-1}\right)$ during ripening (Fig. 6A), while PE activity in skin of treated fruit decreased with increased concentration of 1-MCP applied. PE in the pulp tissue was slightly higher than skin but both tissues exhibited similar pattern of changes in PE activity during ripening (Fig. 6A and 6B).

\subsubsection{Activity of EGase}

1-MCP application suppressed the EGase activity in skin and pulp tissues compared to the control fruit, and suppression was more pronounced at the higher (1.0 and $\left.2.0 \mu \mathrm{L} \mathrm{L}^{-1}\right)$ concentrations of 1-MCP applied. Untreated pulp tissue showed a typical climacteric peak in EGase activity with highest value (260.6 viscosity changes $\mathrm{mg}$ protein ${ }^{-1} \mathrm{~h}^{-1}$ ) on day seven, with a decline on day ten (Fig. 7B). The pulp of fruit treated with $0.5 \mu \mathrm{L} \mathrm{L}^{-1} 1-\mathrm{MCP}$ exhibited a peak (188.17 viscosity changes $\mathrm{mg}$ protein ${ }^{-1} \mathrm{~h}^{-1}$ ) on day seven, similar to that of the control, while higher concentrations did not show any significant increase in pulp EGase activity. Both skin and pulp tissues exhibited a similar pattern of EGase activity but, in pulp tissue the EGase enzyme was two to three-fold more active, compared to skin tissue. Control and $0.5 \mu \mathrm{L} \mathrm{L}^{-1} 1$-MCP-treated skin tissues on day seven showed a peak in EGase activity, but remained 2.5-fold less compared to pulp tissue (Fig. 7A).

\subsubsection{Activity of exo-PG and endo-PG}


The application of 1-MCP significantly reduced the exo-PG and endo-PG activities both in skin (Fig. 8A and 9A) and pulp tissues (Fig. 8B and 9B) compared to untreated control fruit. Reduction in these enzyme activities was concentration dependent and decreased with increased concentrations of 1-MCP applied. In skin tissue of control fruit on day ten, exo-PG was 1.6-fold higher than on day one, while in 1-MCP $\left(0.5,1.0\right.$ and $\left.2.0 \mu \mathrm{L} \mathrm{L}^{-1}\right)$ treated fruit on day ten it increased only up to $1.4,1.2$ and 1.1-fold respectively, compared to day one. In 1-MCP-treated fruit, endo-PG activity was also significantly lower than in untreated control fruit. The activity of endo-PG enzyme in the skin of untreated fruit increased from day one ( 17.53 viscosity changes $\left.\mathrm{mg}_{\text {protein }}{ }^{-1} \mathrm{~h}^{-1}\right)$ to day ten (40.42 viscosity changes mg protein ${ }^{-1} \mathrm{~h}^{-1}$ ), while in 1-MCP-treated fruit skin tissue the activity first slightly declined on day four and, later increased, depending upon concentration of 1-MCP applied. At higher concentration (2.0 $\left.\mu \mathrm{L} \mathrm{L}^{-1}\right)$ of 1-MCP-treated fruit, skin exhibited lower endo-PG activity (21.63 viscosity changes mg protein $\left.{ }^{-1} \mathrm{~h}^{-1}\right)$ than control fruit (40.42 viscosity changes $\mathrm{mg}$ $\operatorname{protein}^{-1} \mathrm{~h}^{-1}$ ). Pulp tissue showed similar trend in endo-PG activity, and the control fruit exhibited higher endo-PG activity $\left(57.58 \mu \mathrm{g}\right.$ gal acid mg protein ${ }^{-1} \mathrm{~h}^{-}$ $\left.{ }^{1}\right)$ than 1-MCP-treated fruit.

\section{Discussion}

\subsection{Ethylene biosynthesis}

As expected, postharvest application of 1-MCP $\left(1.0\right.$ and $\left.2.0 \mu \mathrm{L} \mathrm{L}^{-1}\right)$ suppressed the ethylene production during ripening at ambient temperature 
(Fig.1), while climacteric ethylene production was delayed in 1-MCP-treated fruit, irrespective of the concentration applied. The reduction in ethylene production during fruit ripening in 1-MCP-treated fruit may be due to reduced autocatalytic process, as ethylene binding sites have been irreversibly blocked by 1-MCP (Sisler et al., 1996). Reduction in ethylene production with postharvest application of 1-MCP in different plum cultivars has been reported (Abdi et al., 1998; Dong et al., 2001a; Martinez-Romero et al., 2003a; Salvador et al., 2003a; Skog et al., 2003; Valero et al., 2004). The application of 1-MCP has reported to delay and suppress endogenous ethylene production during ripening in other fruits, such as apple (Fan and Matheis, 1999), apricot (Fan et al., 2000), banana (Pathak et al., 2003), avocado (Jeong and Huber, 2004) and pear (Trinchero et al., 2004). While the untreated fruit exhibited a climacteric peak at day six of ripening, suggesting that 'Tegan Blue' exhibits a typical climacteric ethylene production pattern (Fig. 1A) as also reported in 'Gulferby', 'Beauty' and 'Royal Zee' plum (Abdi et al., 1998; Dong et al., 2002). Reduced climacteric ethylene production in 1-MCP-treated fruit, particularly at higher concentrations, may be ascribed to the reduced activities of ethylene biosynthesis enzymes ACS and ACO as well as ACC content (Fig. 1 and Fig. 3-5). It was further supported with positive significant $(P \leq 0.05 ; P \leq 0.001)$ correlations $(r=0.341 ; r=0.456)$ which were found between ethylene production, as well as ACS activity in skin and pulp respectively. Ethylene production also showed positive significant $(P \leq$ $0.001)$ correlations with the ACO activity in skin $(r=0.261)$ and pulp $(r=$ $0.218)$

Autocatalytic ethylene production was delayed in 1-MCP-treated fruit depending upon the concentration applied as 1-MCP binds to the ethylene 
receptors, thus reducing and delaying autocatalytic ethylene production during ripening (Lalel et al., 2003). It has been observed earlier that, over a period of time, new receptors could be synthesised in 1-MCP-treated fruit, which reduces 1-MCP effectiveness (Jiang et al., 1999). The delayed climacteric ethylene production in fruit treated with 1-MCP $\left(1.0\right.$ and $\left.2.0 \mu \mathrm{L} \mathrm{L}^{-1}\right)$ may be due to the biosynthesis of new ethylene receptors.

\subsection{Ethylene biosynthesis enzymes and ACC content}

Postharvest application of 1-MCP significantly reduced the ACS and ACO activities both in pulp and skin tissues during ripening as compared to untreated fruit. 1-MCP-induced ethylene inhibition is attributed to the ability of 1-MCP to permanently bind to a sufficient number of ethylene receptors (Sisler et al., 1996; Binder and Bleecker, 2003), consequently reducing the normal increase in ACS and ACO enzyme activities during ripening (Nakatsuka et al., 1997; Dong et al., 2002). In nectarines, 1-MCP treatment has been reported to inhibit transcription of ACO genes during ripening (Dong et al., 2001b), which shows that inhibition in ethylene production with 1-MCP treatment is regulated at gene level. Ethylene production in control fruit (Fig.1A) exhibited a typical climacteric peak that was accompanied by increase in ACS and ACO activities (Fig. 3 and 4), while suppression in the activities of these enzymes in 1-MCPtreated fruit tissue may be ascribed to the inhibitory effect of 1-MCP on the accumulation of their respective mRNAs. Following 1-MCP application, a significant delay in the induction of ethylene biosynthesis and PP-ACSI and PP- 
ACOI genes have also been reported in pear (Lelievre et al., 1997b) and tomato (Nakatsuka et al., 1997).

The activity of ACO in the skin as well as in pulp tissues of untreated and $0.5 \mu \mathrm{L} \mathrm{L}^{-1} 1$-MCP-treated fruit peaked and synchronised with the rise in the ethylene production and such a trend of ACS activity in skin and pulp of fruit was not recorded (Fig. 3 and 4). Possibly the different pattern in the activities of ACS and ACO during plum fruit ripening may be ascribed to the differential accumulation of ACS and ACO transcripts as also observed in banana (Pathak et al., 2003), where a different mechanism of ACO gene induction was suggested during fruit ripening. The reduction in the ACC content in skin and pulp tissues of 1-MCP-treated fruit may have resulted from reduced activity of ACS in the skin as well as in the pulp. It may also be argued that the reduction in the ACC content in skin and pulp tissues of 1-MCP-treated fruit is due to conversion of ACC to malonyl or glutamylamino derivatives instead of ethylene production, which previously has been studied that ACC malonylation is a contributing factor in pre climacteric fruit (Lelievre et al., 1997a; Genard and Gouble, 2005). Likewise, in 1-MCP-treated banana fruit the onset of autocatalytic ethylene production and ethylene climacteric was delayed with increased amount of malonylation(Golding et al., 1998).

\subsection{Fruit firmness and fruit softening enzymes}

The effect of 1-MCP on fruit firmness was concentration dependant and loss of fruit firmness was high in lower $\left(0.5 \mu \mathrm{L} \mathrm{L}^{-1}\right)$ compared to higher $(1.0$ and $2.0 \mu \mathrm{L} \mathrm{L}^{-1}$ ) 1-MCP concentration. 1-MCP-treated fruit maintained higher 
firmness during the period of fruit ripening as compared to untreated fruit. The reduction in plum fruit softening with 1-MCP treatment may be ascribed to the reduced activities of fruit softening enzymes, as fruit firmness showed a significant negative correlation with activities of different softening enzymes. Similarly, delayed fruit softening in 1-MCP-treated fruit has been reported in various fruits such as banana (Lohani et al., 2004), papaya (Hofman et al., 2001), apple (Watkins et al., 2000), apricot (Fan et al., 2000), avocado (Jeong et al., 2002), peach (Fan et al., 2002), plum (Martinez-Romero et al., 2003b; Skog et al., 2003; Menniti et al., 2004).

The cell wall hydrolytic enzymes play a key role in cell wall degradation and softening of fruits. Changes in polymerisation and sugar composition of polysaccharide are associated with alteration of cell wall structure of fruit tissue (Fischer and Bennett, 1991). Postharvest application of 1-MCP significantly affected the activities of softening enzymes in plum fruit. PE activity both in skin and pulp tissues decreased with increased concentrations of 1-MCP applied. Higher PE activity in control fruit skin and pulp tissues revealed that, during ripening 1-MCP affects the demethylation and cleavage of pectin in 'Tegan Blue' plum skin and pulp tissues as earlier reported (Lohani et al., 2004). Likewise, in banana, postharvest application of $1.0 \mu \mathrm{L} \mathrm{L}^{-1} 1-\mathrm{MCP}$ suppressed the PME activity (Lohani et al., 2004); contrarily (Dong et al., 2001a) did not observe any change in activity of PE and endo-PG enzymes in 1-MCP-treated 'Red Rosa' plum fruit during ripening and after storage, compared to that of untreated control fruit.

EGase activity increased in the fruit skin and pulp with advancement of ripening, and peaked on day seven in untreated and in $0.5 \mu \mathrm{L} \mathrm{L}^{-1} 1-\mathrm{MCP}$ treated 
fruit tissue and declined on day 10. Fruit treated with 1-MCP, particularly at higher concentrations, showed complete suppression of activity of EGase enzyme in skin and pulp. A similar trend of EGase activity was observed in banana fruit as the enzyme activity increased gradually up to day four (17-fold higher than day zero) and thereafter decreased significantly until day seven (Lohani et al., 2004). No EGase activity was detected in avocado fruit initially during $24 \mathrm{hrs}$ following 1-MCP treatment in both treated and untreated fruit and it increased after day four in control but treated fruit maintained lower enzyme activity (Jeong et al., 2002).

Fruit treated with 1-MCP showed reduced activities of exo-PG and endoPG enzymes during plum fruit ripening (Fig. 8 and 9) and the reduction was more pronounced at the higher concentrations of 1-MCP applied. Maximum exo-PG and endo-PG was observed on day ten, which coincided with the activity of PE during ripening in 'Tegan Blue' skin and pulp tissues. (Fig. 7 and 8). PE demethylates, the $\mathrm{C} 6$ position of galacturonic acid polymer, which facilitates $\mathrm{PG}$ to act preferentially on the demethylated substrate provided by the activity of PE (Koch and Nevins, 1989). Similar changes in PME have been reported in pear (Ahmed and Labavitch, 1980; Zhou et al., 2000) and strong inhibition of PG and PE activity was observed in 1-MCP-treated avocado fruit (Feng et al., 2000; Jeong et al., 2002). The action of PE has been observed as prerequisite for optimal PG activity in tomato fruit (Koch and Nevins, 1989). The activity of PE in 'Tegan Blue' plum preceded the activity of PG both in skin and pulp tissues indicating the coordinated action of both enzymes during plum fruit ripening.

\subsection{Role of ethylene and fruit softening enzymes in fruit softening}


As a prelude, skin and pulp tissues of 1-MCP-treated fruit showed reduced activity of ACS, ACO and ACC content consequently ethylene biosynthesis as well as activity of various fruit softening enzymes such as PE, EGase, exo-PG, and endo-PG. The activities of softening enzymes were significantly negatively correlated to changes in fruit firmness and positively correlated to ethylene production during fruit ripening. A significant $(P \leq 0.001)$ negative correlation $(\mathrm{r}=-0.737)$ was found between ethylene production and fruit firmness as influenced with 1-MCP treatments. ACS activity in the skin $(r=$ $-0.788)$ and pulp $(\mathrm{r}=-0.819)$ was significantly $(P \leq 0.001)$ negatively correlated with fruit firmness. Plum fruit firmness was found to be negatively correlated $(P$ $\leq 0.001)$ with ACO activity in skin $(r=-0.725)$ and pulp $(r=-0.737)$. Fruit firmness showed a significantly $(P \leq 0.001)$ negative correlation with ACC content in skin $(r=-0.737)$ and pulp $(r=-0.702)$, as regulated with 1-MCP treatments. Plum fruit firmness showed a significant negative $(P \leq 0.001)$ correlation with ACO activity in skin $(r=-0.893)$ and pulp $(r=-0.863)$, while ethylene production showed a significant $(P \leq 0.001)$ positive correlation with PE activity in skin $(r=0.521)$ and pulp $(r=0.535)$ tissues. High significant negative correlations were detected between fruit firmness and activity of ethylene biosynthesis enzymes, both in the skin and in pulp tissues, which confirms the role of ethylene in softening of fruit tissue during ripening. A significant negative correlation between fruit firmness and ethylene production further confirmed the regulatory role of ethylene in softening of plum fruit. Similarly, ethylene production has been reported to increase fruit softening in some plum cultivars (Abdi et al., 1997b; Jobling et al., 2003). 
EGase activity in skin and pulp of 1-MCP-treated fruit showed significant $(P \leq 0.001)$ negative correlations $(r=-0.799$ and -0.82$)$ with fruit firmness respectively, while the activity of EGase in the skin and pulp of 1-MCP-treated fruit showed significant $(P \leq 0.001)$ positive correlation with ethylene production $(\mathrm{r}=0.468$ and $\mathrm{r}=0.511)$ respectively during fruit ripening. In fruit skin and pulp, exo-PG activities exhibited a significant $(P \leq 0.001)$ negative correlations $(\mathrm{r}=$ $0.882,-0.876$ ) with fruit firmness of 1-MCP-treated fruit respectively, while endo-PG activities showed a significant $(P \leq 0.001)$ positive correlation $(\mathrm{r}=$ $0.544,0.468$ ) with ethylene production in skin and pulp tissues respectively. As ethylene has been known to play multiple roles in regulation of different ethylene dependant ripening processes and each process may have different sensitivity to ethylene. The treatment of 1-MCP delayed plum fruit softening through reduced ethylene production, as well as its action and/or directly reducing the activity of fruit softening enzymes in pulp and skin of fruit.

\section{Conclusion}

In conclusion, 'Tegan Blue' plum fruit treated with $1.0 \mu \mathrm{L} \mathrm{L}^{-1} 1-\mathrm{MCP}$ for 24 hours at $20^{\circ} \mathrm{C}$ exhibited suppressed and delayed ethylene production and reduced the activities of ethylene biosynthesis enzymes (ACS, ACO) and ACC content, as well as fruit softening enzymes (PE, EGase, exo-PG and endo-PG) in fruit skin and pulp tissues. This may be attributed directly to the reduced ethylene biosynthesis and/or inhibitory effect of 1-MCP on these fruit softening enzymes. 1-MCP-treated fruit also showed differential activity of fruit softening and ethylene biosynthetic enzymes in the skin and pulp tissues, which warrants 
further investigations on its effects on the gene expression related to these enzymes.

\section{Acknowledgements}

We are thankful to Dr G. Seymour, Horticultural Research International, Warwick, UK for his constructive review and comments on the manuscript and Dr J. Dawson, Curtin University of Technology, Perth, Western Australia for editing the manuscript. A. S. Khan acknowledges the financial support from Higher Education Commission, Pakistan for awarding scholarship under the programme "Partial Support for PhD Studies Aborad" and Curtin University of Technology for granting International Postgraduate Research Scholarship during his $\mathrm{PhD}$ studies. He also acknowledges Institute of Horticultural Sciences, University of Agriculture Faisalabad, Pakistan for granting him study leave for the whole study period. We thank Mrs. Alicia Pasznicki, Manager, Postharvest Horticulture Laboratory at Curtin University of Technology for her assistance in the laboratory work. We are thankful to Mr. Satvinder Dhaliwal, Biostatistician, at Curtin University of Technology for his help in statistical analysis of the experimental data. We also thank Casuarina Valley Orchard Manjimup, Western Australia for providing the plum fruit for the research. 


\section{References}

2

3

4

Abdi, N., Holford, P., McGlasson, W.B., Mizrahi, Y., 1997a. Ripening behaviour and responses to propylene in four cultivars of Japanese type plums. Postharvest Biology and Technology. 12, 21-34.

Abdi, N., McGlasson, W.B., Holford, P., Mizrahi, Y., 1997b. Towards the development of new indices of harvest maturity and prolonged storage life of stone fruit. Future environmental challenges for stone fruit growers: Stone fruit Field Day, 6th , 22 April 1997, Bathurst NSW, Proceedings, hardy, s (ed). NSW Agriculture, s.1., 1997, D 634.2/11, 67-68.

Abdi, N., McGlasson, W.B., Holford, P., Williams, M., Mizrahi, Y., 1998. Responses of climacteric and suppressed-climacteric plums to treatment with propylene and 1-methylcyclopropene. Postharvest Biology and Technology. 14, 29-39.

Ahmed, A.E., Labavitch, J.M., 1980. Cell wall metabolism in fruit. II: Changes in carbohydrate-degrading enzymes in ripening 'Bartlett' pears. Plant Physiology. $65,1014-1016$.

Alexander, L., Grierson, D., 2002. Ethylene biosynthesis and action in tomato: a model for climacteric fruit ripening. Journal of Experimental Botany. 53, 20392055.

Binder, B.M., Bleecker, A.B., 2003. A model for ethylene receptor function and 1Methylcyclopropane action. Acta Horticulturae. 628, 177-187.

Blankenship, S.M., Dole, J.M., 2003. 1-Methylcyclopropane: a review. Postharvest Biology and Technology. 28, 1-25. 
1 Bradford, M.M., 1976. A rapid and sensitive method for the quatitation of microgram

2 quantities of protein utilizing the principles of protein-dye binding. Analytical Biochemistry. 72, 248-254.

Dong, L., Zhou, H.W., Sonego, L., Lers, A., Lurie, S., 2001a. Ripening of 'Red Rosa' plums: effect of ethylene and 1-methylcyclopropene. Australian Journal of Plant Physiology. 28, 1039-1045.

Dong, L., Zhou, H.W., Sonego, L., Lers, A., Lurie, S., 2001b. Ethylene involvement in the cold storage disorder of 'Flavortop" nectarine. Postharvest Biology and Technology. 23, 105-115.

Dong, L., Lurie, S., Zhou, H.-W., 2002. Effect of 1-methylcyclopropene on ripening of 'Canino' apricots and 'Royal Zee' plums. Postharvest Biology and Technology. 24, 135-145.

Environmental Protection Agency, 2002. Federal Register. 67, 48796-48800.

Fan, X., Matheis, J.P., 1999. Impact of 1-methylcyclopropene and methyl jasmonate on apple volatile production. Journal of Agricultural and Food Chemistry. 47, $2847-2853$.

Fan, X., Argenta, L., Mattheis, J.P., 2000. Inhibition of ethylene action by 1methylcyclopropene prolongs storage life of apricots. Postharvest Biology and Technology. 20, 135-142.

Fan, X., Argenta, L., Mattheis, J.P., 2002. Interactive effects of 1-MCP and temperature on 'Elberta' peach quality. Hortscience. 37, 134-138.

Feng, X., Apelbaum, A., Sisler, E.C., Goren, R., 2000. Control of ethylene responses in avocado fruit with 1-methylcyclopropene. Postharvest Biology and Technology. 20, 143-150. 
1 Fischer, R.L., Bennett, A.B., 1991. Role of cell wall hydrolysis in fruit ripening. Annual Review of Plant Physiology and Plant Molecular Biology. 42, 675-703.

Genard, M., Gouble, B., 2005. ETHY. A theory of fruit climacteric ethylene emission. Plant Physiology. 139, 531-545.

Golding, J.B., Shearer, D., Wyllie, S.G., McGlasson, W.B., 1998. Application of 1$\mathrm{MCP}$ and propylene to identify ethylene dependent ripening processes in mature banana fruit. Postharvest Biology and Technology. 14, 87-98.

Gong, Y., Fan, X., Mattheis, J.P., 2002. Responses of 'Bing' and 'Rainier' sweet cherries to ethylene an 1-metycyclopropane. Journal of American Society for Horticultural Science. 127, 831-835.

Gross, K.C., 1982. A rapid and sensitive spectrophotometric method for assaying polygalacturonase using 2-cyanoacetamide. HortScience. 17, 933-934.

Hiwasa, K., Kinugasa, Y., Amano, S., Hashimoto, A., Nakano, R., Inaba, A., Kubo, Y., 2003. Ethylene is required for both the initiation and progression of softening in pear (Pyrus communis L.) fruit. Journal of Experimental Botany. $54,771-779$.

Hofman, P.J., Jobin-Decor, M., Meiburg, G.F., Macnish, A.J., Joyce, D.C., 2001. Ripening and quality responses of avocado, custard apple, mango and papaya fruit to 1-methylcyclopropane. Australian Journal of Experimental Agriculture. $41,567-572$.

Jeong, J., Huber, D.J., Sargent, S.A., 2002. Influence of 1-methylcyclopropene (1$\mathrm{MCP}$ ) on ripening and cell-wall matrix polysaccharides of avocado (Persea americana) fruit. Postharvest Biology and Technology. 25, 241-256.

Jeong, J., Huber, D.J., 2004. Suppression of avocado (Persea americana Mill.) fruit softening and changes in cell wall matrix polysaccharides and enzymes activites: 
1 Differential responses to 1-MCP and delayed ethylene application. Journal of

2 American Society for Horticultural Science. 129, 752-759.

3 Jiang, Y.M., Joyce, D.C., Macnish, A.J., 1999. Responses of banana fruit to

4 treatment with 1-methylcyclopropene. Plant Growth Regulation. 28, 77-82.

5 Jobling, J., Pradhan, R., Morris, S.C., Mitchell, L., Rath, A.C., 2003. The effect of

6 ReTain plant growth regulator [aminoethoxyvinylglycine (AVG)] on the

7 postharvest storage life of 'Tegan Blue' plums. Australian Journal of

$8 \quad$ Experimental Agriculture 43, 515-518.

9 Khan, A.S., Singh, Z., 2004. Postharvest application of 1-MCP affects ethylene

10 biosynthesis and firmness of 'Tegan Blue' plum. Acta Horticulturae. 687, 409-

11410.

12 Koch, J.L., Nevins, D.J., 1989. Tomato fruit cell wall. I. Use of purified tomato

13 polygalacturonase and pectin methylesterase to identify development changes in

14 pectins. Plant Physiology. 91, 816-822.

15 Lalel, H.J.D., Singh, Z., Tan, S.C., 2003. The role of ethylene in mango fruit aroma

16 volatiles biosynthesis. Journal of Horticultural Science \& Biotechnology. 78,

$17 \quad 485-496$.

18 Lashbrook, C.C., Gonzalez-Bosch, C., Bennett, A.B., 1994. Two divergent endo-1,4-

19 B-D-glucanase genes exhibit overlapping expression in ripening fruit and

20 abscising flowers. The Plant Cell. 6, 1485-1493.

21 Lelievre, J.M., Latche, A., Jones, B., Bouzayen, M., Pech, J.C., 1997a. Ethylene

22 and fruit ripening. Physiologia Plantarum. 101, 727-739.

23 Lelievre, J.M., Tichit, L., Dao, P., Fillion, L., Nam, Y.W., Pech, J.C., Latche, A., 24 1997b. Effect of chilling on the expression of ethylene biosynthetic genes in 

855.

3 Liguori, G., Weksler, A., Zutahi, Y., Lurie, S., Kosto, I., 2004. Effect of 1-

4 methylcyclopropene on ripening of melting flesh peaches and nectarines.

Postharvest Biology and Technology. 31, 263-268.

Lohani, S., Trivedi, P.K., Nath, P., 2004. Changes in activities of cell wall hydrolases during ethylene-induced ripening in banana: effect of 1-MCP, ABA and IAA. Postharvest Biology and Technology. 31, 119-126.

Marin-Rodriguez, M.C., Orchard, J., Seymour, G.B., 2002. Pectate lyases, cell wall degradation and fruit softening. Journal of Experimental Botany. 53, 2115-2119.

Martinez-Romero, D., Dupille, E., Guillen, F., Valverde, J.M., Serrano, M., Valero, D., 2003a. 1-Methylcyclopropene increases storability and shelf life in climacteric and nonclimacteric plums. Journal of Agricultural and Food Chemistry. 51, 4680-4686.

Martinez-Romero, D., Serrano, M., Guillen, F., Valero, D., 2003b. 1Methylcyclopropane increased storability in plum (Prunus salicina Lindl. cv. Golden Japan). Acta Horticulturae. 599, 71-77.

Mathooko, F.M., Tsunashima, Y., Owino, W.Z.O., Kubo, Y., Inaba, A., 2001. Regulation of genes encoding ethylene biosynthetic enzymes in peach (Prunus persica L.) fruit by carbon dioxide and 1-methylcyclopropene. Postharvest Biology and Technology. 21, 265-281.

Menniti, A.M., Gregori, R., Donati, I., 2004. 1-Methylcyclopropene retards postharvest softening of plums. Postharvest Biology and Technology. 31, 269275. 
1 Nakatsuka, A., Shiomi, S., Kubo, Y., Inaba, A., 1997. Expression and internal feedback regulation of ACC synthase and ACC oxidase genes in ripening tomato fruit. Plant Cell and Physiology. 38, 1103-1110.

Pathak, N., Asif, M.H., Dhawan, P., Srivastava, M.K., Nath, P., 2003. Expression and activities of ethylene biosynthesis enzymes during ripening of banana fruit and effect of 1-MCP treatment. Plant Growth Regulation. 40, 11-19.

Salvador, A., Cuquerella, J., Martinez-Javega, J.M., 2003a. 1-MCP treatment prolongs postharvest life of 'Santa Rosa' plums. Journal of Food Science. 68, 1504-1510.

Salvador, A., Cuquerella, J., Ubeda, S., 2003b. 1-Methylcyclopropane delay ripening process of 'Black Diomand' plum. Acta Horticulturae. 599, 59-63.

Seymour, G.B., Gross, K.C., 1996. Cell wall disassembly and fruit softening. Postharvest News Information. 7, 45N-52N.

Sisler, E.C., Dupille, E., Serek, M., 1996. Effects of 1-methylcyclopropane and methylcyclppropane on ethylene binding and ethylene action on cut carnation. Plant Growth Regulation. 18, 79-86.

Sisler, E.C., Serek, M., 1997. Inhibitors of ethylene responses in plants at the receptor level. Recent developments. Physiologia Plantarum. 100, 577-582.

Sitrit, Y., Bennett, A.B., 1998. Regulation of tomato fruit polygalacturonase mRNA accumulation by ethylene: A re-examination. Plant Physiology. 116, 1145-1150.

Skog, L.J., Schaefer, B.H., Smith, P.G., 2001. 1-Methylcyclopropane preserves the firmness of plums during postharvest storage and ripening. Acta Horticulturae. $553,171-172$. 
1 Skog, L.J., Schaefer, B.H., Smith, P.G., 2003. Effect of ripeness at harvest on

2

3

4 response of plum to treatment with 1-Methylcyclopropane. Acta Horticulturae. $599,49-52$

Trinchero, G.D., Sozzi, G.O., Covatta, F., Fraschina, A.A., 2004. Inhibition of ethylene action by 1-methylcyclopropene extends postharvest life of "Bartlett" pears. Postharvest Biology and Technology. 32, 193-204.

Valero, D., Martinez-Romero, D., Valverde, J.M., Guillen, F., Serrano, M., 2003. Quality improvement and extension of shelf life by 1-methylcyclopropene in plum as affected by ripening stage at harvest. Innovative Food Science and Emerging Technologies. 4, 339-348.

Valero, D., Martinez-Romero, D., Valverde, J.M., Guillen, F., Castillo, S., Serrano, M., 2004. Could the 1-MCP treatment effectiveness in plum be affected by packaging? Postharvest Biology and Technology. 34, 295-303.

Watkins, C.B., Nock, J.F., Whitaker, B.D., 2000. Responses of early, mid and later season apple cultivars to postharvest application of 1-methylcyclopropane(1MCP) under air and controlled atmosphere storage conditions. Postharvest Biology and Technology. 19, 17-32.

Zhou, H.W., Ben, A.R., Lurie, S., 2000. Pectin esterase, polygalacturonase and gel formation in peach pectic fractions. Phytochemistry. 55, 191-195. 


\section{$1 \quad$ Legends for figures:}

$2 \quad$ Fig. 1

3 Effects of 1-MCP application on the ethylene production during fruit ripening in

4 'Tegan Blue' plum. $\mathrm{n}=3$ replicate. Vertical bars represent standard error of means.

$5 \operatorname{LSD}(P \leq 0.05)$ for ethylene production: Concentration $=0.079$, ripening time $=$

$6 \quad 0.157$, concentration $\mathrm{x}$ ripening time $=0.315$.

7

$8 \quad$ Fig. 2

9 Effects of 1-MCP application on the fruit firmness during fruit ripening in `Tegan

10 Blue' plum. $\mathrm{n}=24$ ( 3 replicate, 8 fruit per replication). Vertical bars represent

11 standard error of means. LSD $(P \leq 0.05)$ for fruit firmness: concentration $=1.037$,

12 ripening time $=1.037$, concentration $\mathrm{x}$ ripening time $=2.074$.

13

14 Fig. 3

15 Effects of 1-MCP application on the ACS activity of fruit (A) Skin (B) Pulp during

16 fruit ripening in 'Tegan Blue' plum. $\mathrm{n}=3$ replicate. Vertical bars represent standard

17 error of means. $\operatorname{LSD}(P \leq 0.05)$ for Skin ACS: concentration $=0.066$, ripening time $=$

180.066 , concentration $\mathrm{x}$ ripening time $=0.132$. ACS pulp: concentration $=0.006$,

19 ripening time $=0.006$, concentration $\mathrm{x}$ ripening time $=0.012$. 
$1 \quad$ Fig. 4

2 Effects of 1-MCP application on the ACO activity of fruit (A) Skin (B) Pulp during

3 fruit ripening in 'Tegan Blue' plum. $\mathrm{n}=3$ replicate. Vertical bars represent standard

4 error of means. $\operatorname{LSD}(P \leq 0.05)$ for Skin ACO: concentration $=1.67$, ripening time $=$

5 1.67, concentration $\mathrm{x}$ ripening time $=3.341$. Pulp ACO: concentration $=0.244$,

6 ripening time $=0.244$, concentration $\mathrm{x}$ ripening time $=0.488$.

7

8 Fig. 5

9 Effects of 1-MCP application on the ACC content of fruit (A) Skin (B) Pulp during

10 fruit ripening in `Tegan Blue plum. $\mathrm{n}=3$ replicate. Vertical bars represent standard

11 error of means. $\operatorname{LSD}(P \leq 0.05)$ for Skin $\mathrm{ACC}$ : concentration $=0.567$, ripening time $=$

120.567 , concentration $\mathrm{x}$ ripening time $=1.134$. Pulp ACC: concentration $=0.514$,

13 ripening time $=0.514$, concentration $\mathrm{x}$ ripening time $=1.0296$.

14

15 Fig. 6

16 Effects of 1-MCP application on the PE activity of fruit (A) Skin (B) pulp during fruit

17 ripening in 'Tegan Blue' plum. $\mathrm{n}=3$ replicate. Vertical bars represent standard error

18 of means. $\operatorname{LSD}(P \leq 0.05)$ for Skin PE: concentration $=0.0092$, ripening time $=$

190.0092 , concentration $\mathrm{x}$ ripening time $=0.0184$. Pulp PE: concentration $=0.0118$,

20 ripening time $=0.0117$, concentration $\mathrm{x}$ ripening time $=0.0235$. 
$1 \quad$ Fig. 7

2 Effects of 1-MCP application on EGase activity of fruit (A) Skin (B) Pulp during fruit

3 ripening in 'Tegan Blue' Plum. $\mathrm{n}=3$ replicate. Vertical bars represent standard error

4 of means. $\operatorname{LSD}(P \leq 0.05)$ for Skin EGase: concentration $=2.758$, ripening time $=$

52.758 , concentration $\mathrm{x}$ ripening time $=5.16$. Pulp EGase: concentration $=3.15$,

6 ripening time $=3.15$, concentration $\mathrm{x}$ ripening time $=6.3$.

7

8 Fig. 8

9 Effects of 1-MCP application on exo-PG activity of fruit (A) Skin (B) Pulp during

10 fruit ripening in 'Tegan Blue' plum. $\mathrm{n}=3$ replicate. Vertical bars represent standard

11 error of means. LSD $(P \leq 0.05)$ for Skin exo-PG: concentration $=3.68$, ripening time

$12=3.68$, concentration $\mathrm{x}$ ripening time $=7.36$. Pulp exo-PG: concentration $=5.06$,

13 ripening time $=5.06$, concentration $\mathrm{x}$ ripening time $=10.11$.

14

$15 \quad$ Fig. 9

16 Effects of 1-MCP application on endo-PG activity of fruit (A) Skin (B) Pulp during

17 ripening in 'Tegan Blue' plum. $\mathrm{n}=3$ replicate. Vertical bars represent standard error

18 of means. $\operatorname{LSD}(P \leq 0.05)$ for Skin endo-PG: concentration $=2.63$, ripening time $=$

19 2.63, concentration $\mathrm{x}$ ripening time $=5.26$. Pulp endo-PG: concentration $=2.35$,

20 ripening time $=2.35$, concentration $\mathrm{x}$ ripening time $=4.69$. 
Figure $1 \quad$ Khan and Singh

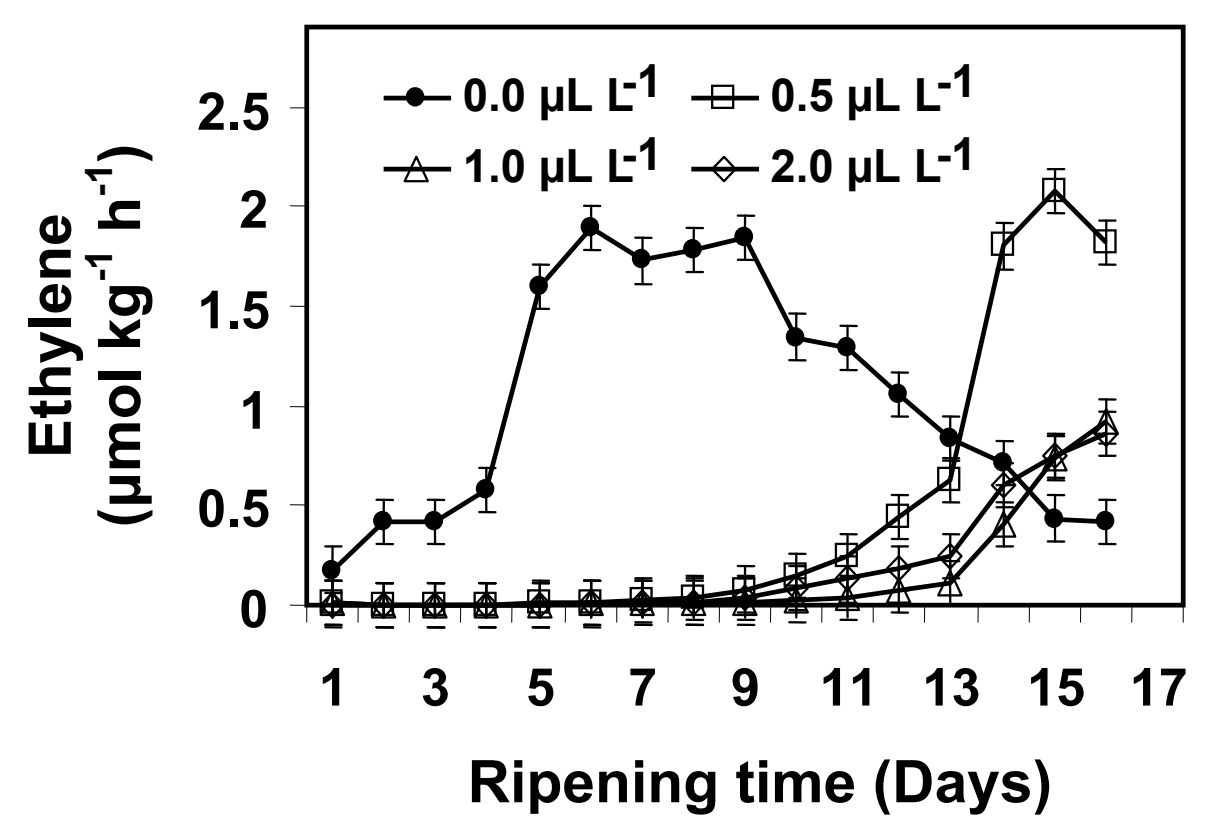


Figure $2 \quad$ Khan and Singh

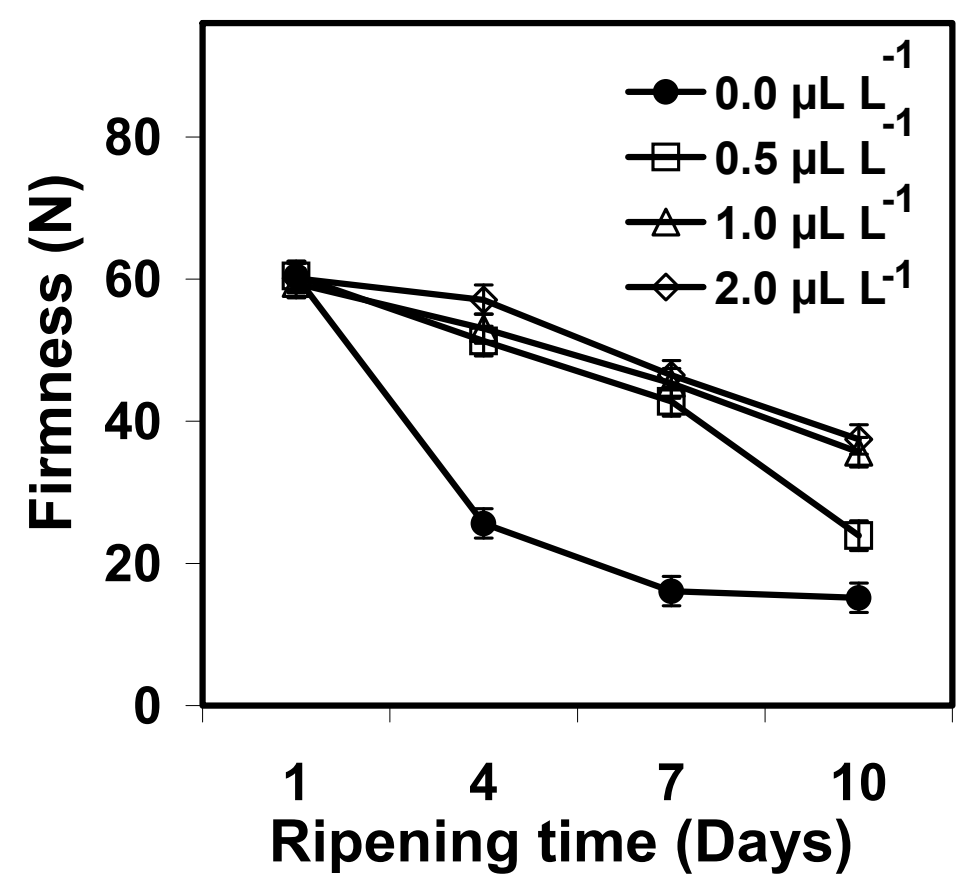


Figure $3 \quad$ Khan and Singh

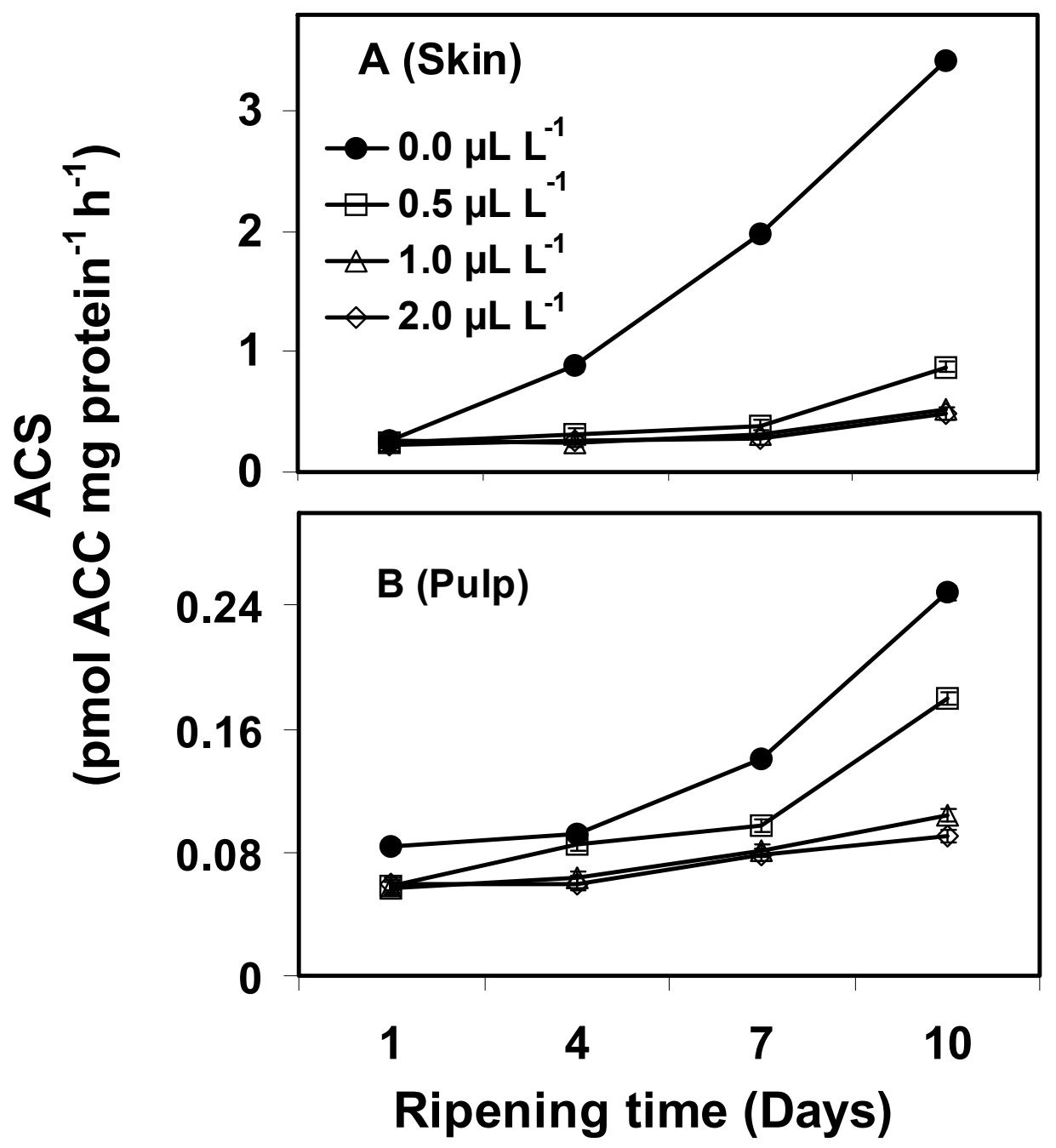


Figure $4 \quad$ Khan and Singh

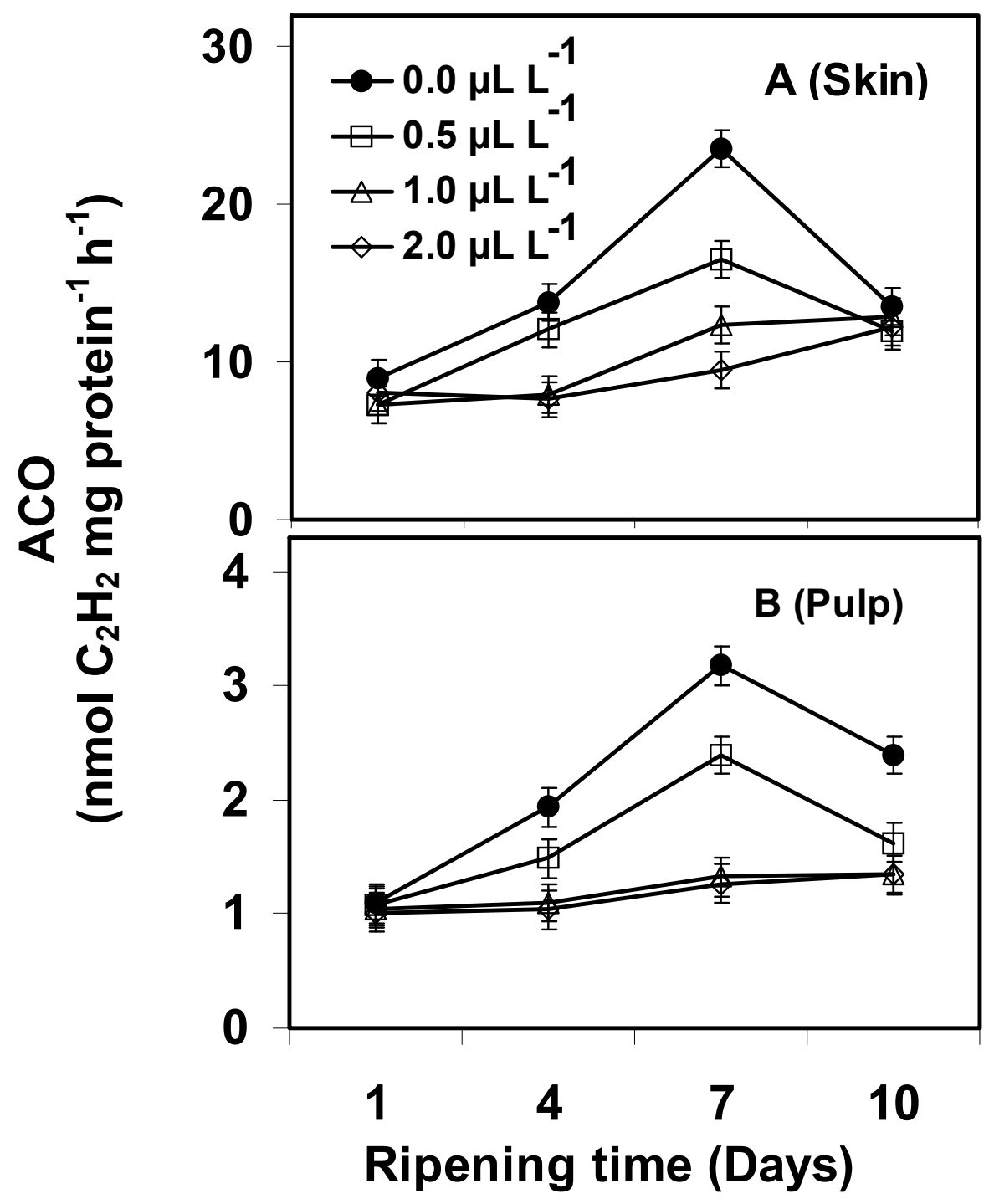


Figure $5 \quad$ Khan and Singh

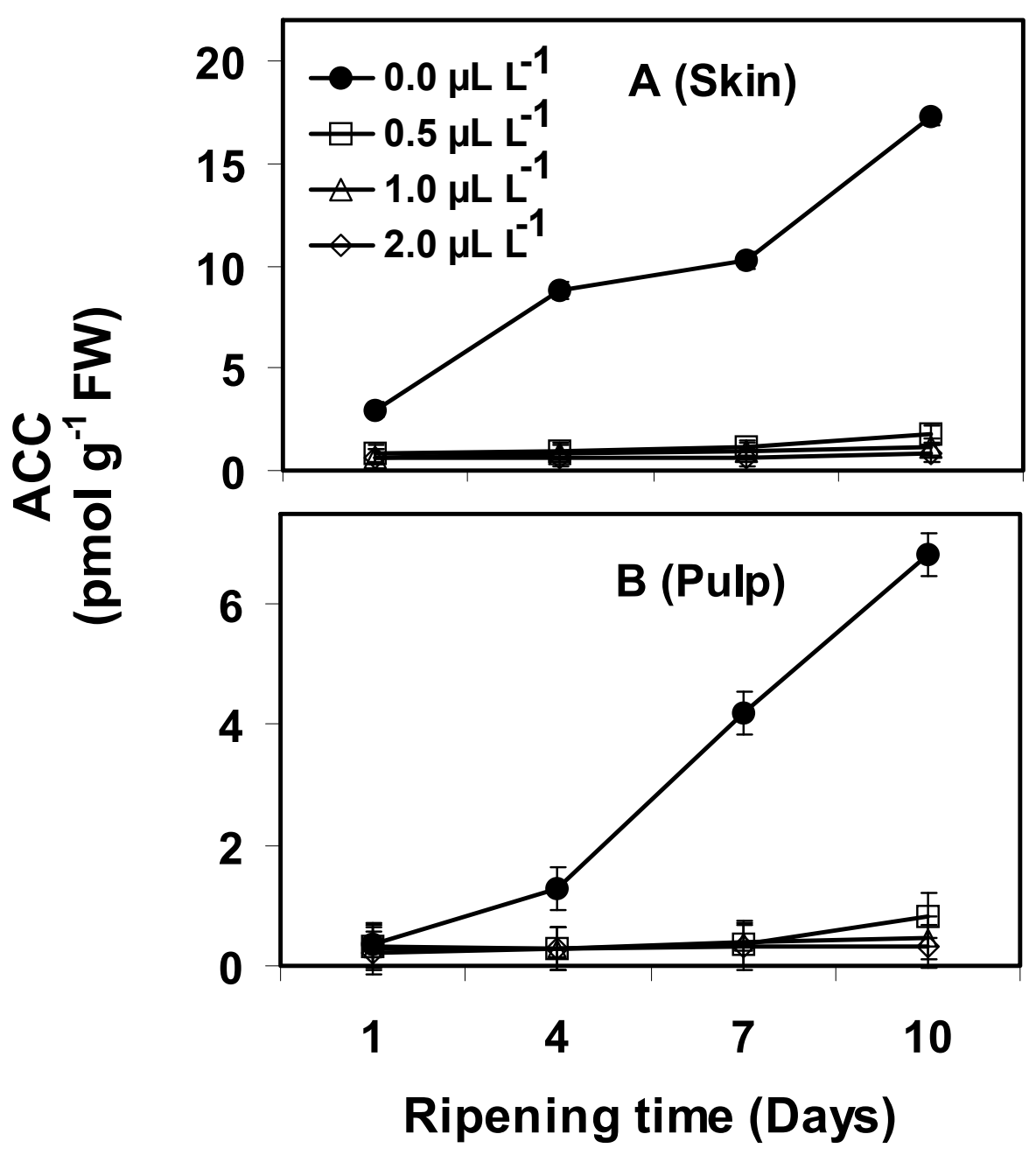


Figure $6 \quad$ Khan and Singh

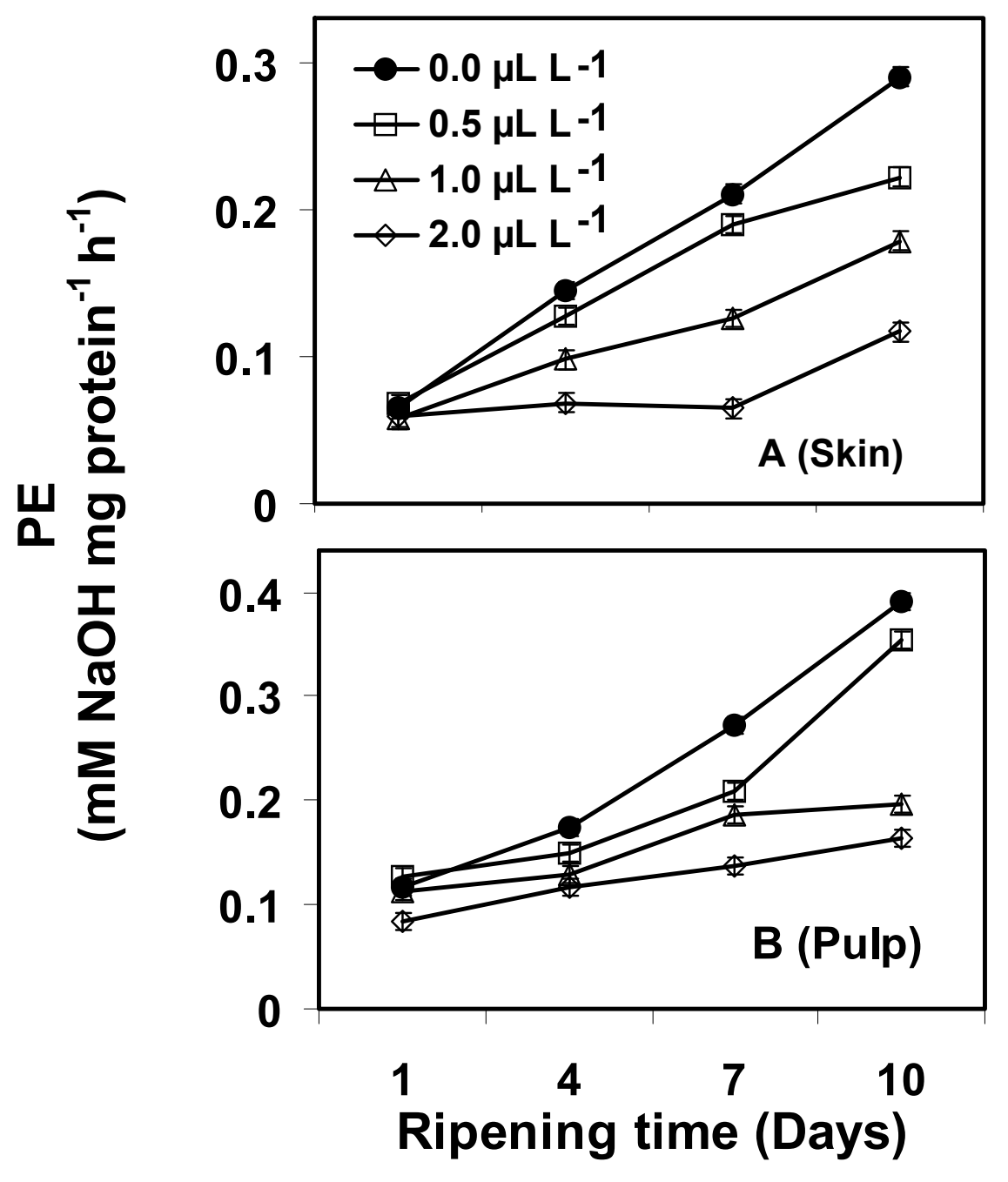


Figure $7 \quad$ Khan and Singh

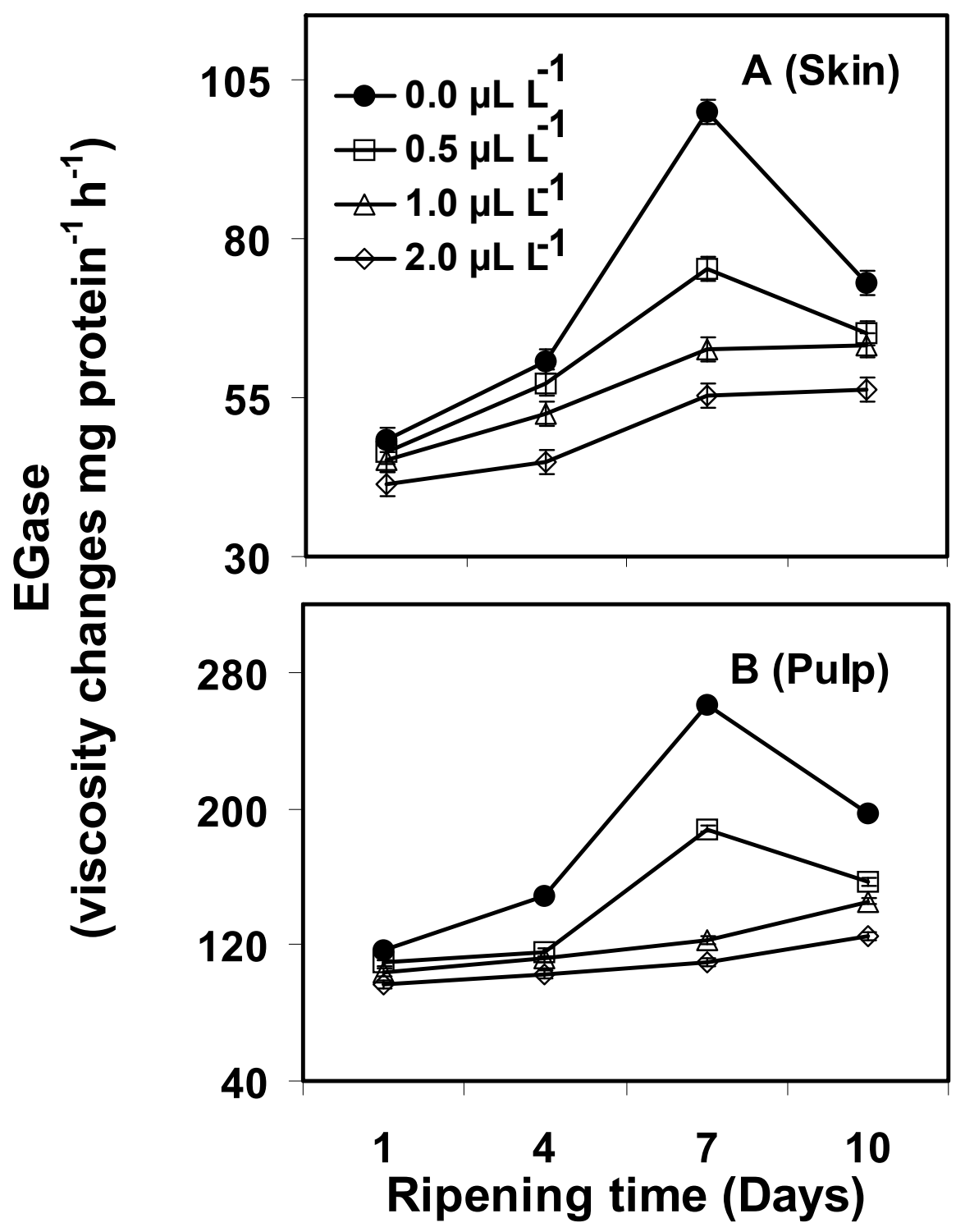


Figure 8 Khan and Singh

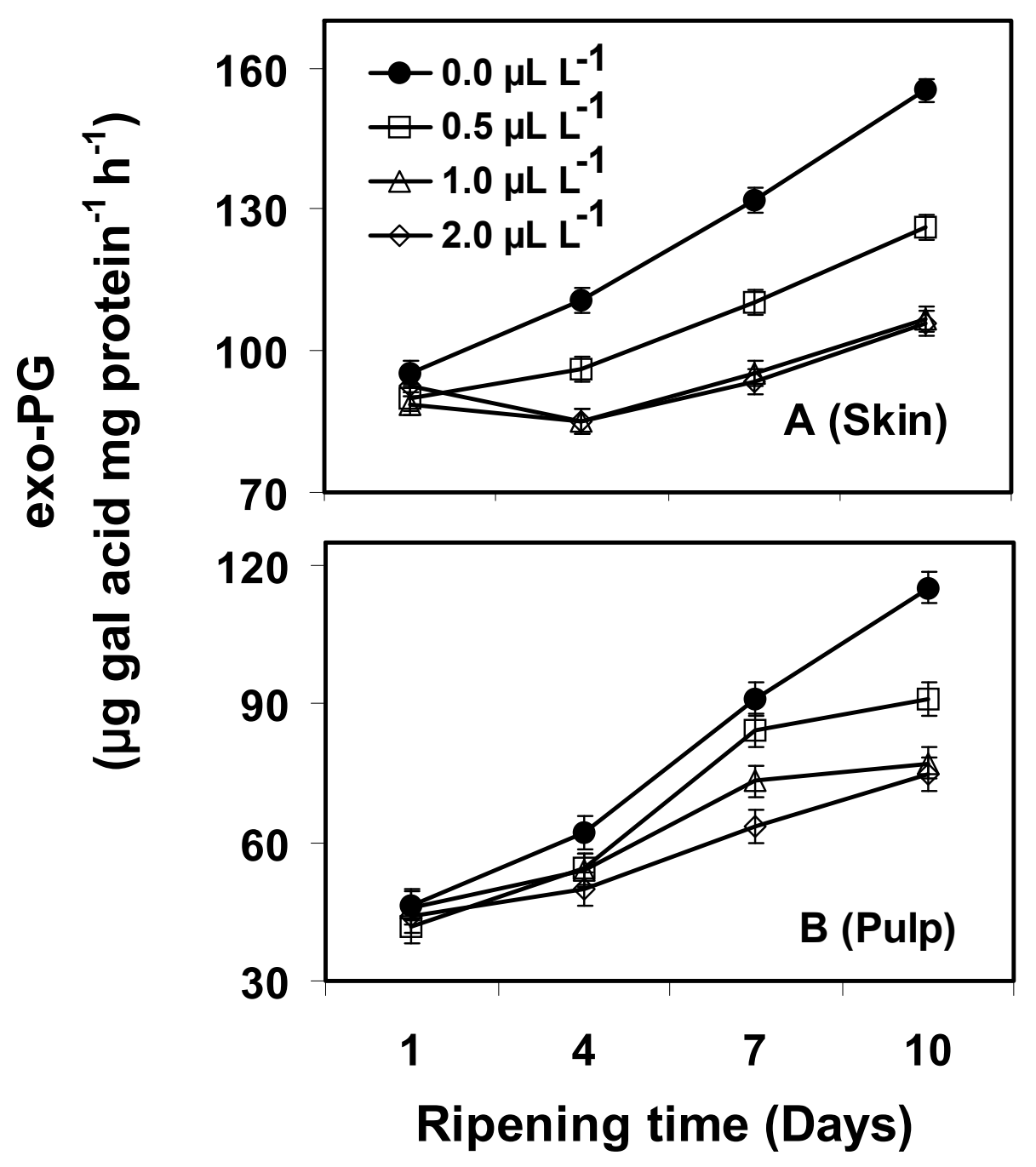


Figure 9 Khan and Singh

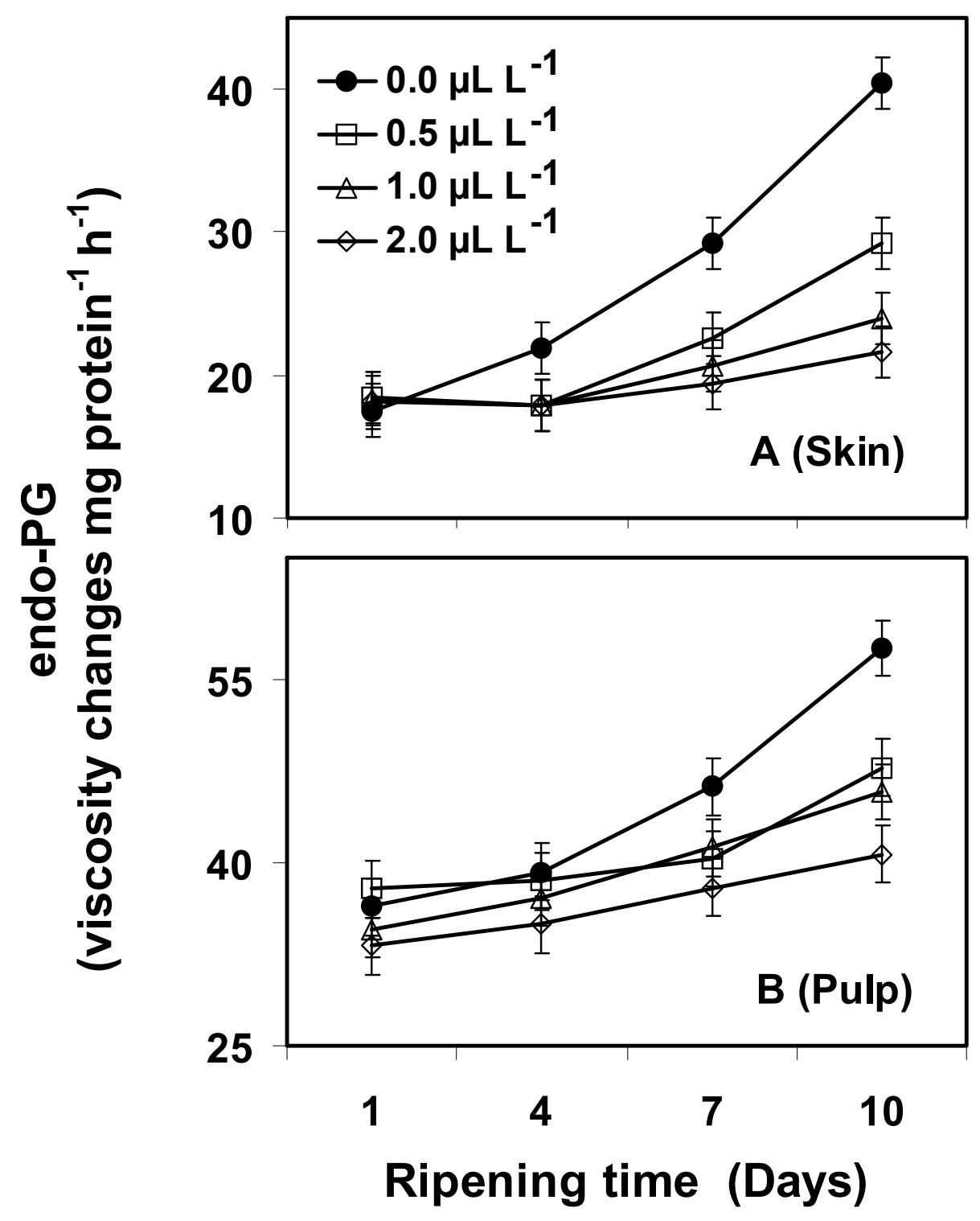

